\title{
NOTES ON THE MUNSHI TRIBE AND LANGUAGE
}

THE Munshi is one of the largest tribes in the Northern Province of Northern Nigeria. Numerically it is some 200,000 strong. A reference to the map will show where 8th degree North crosses 9th degree West. Here in Muri Province is the country of the Munshis. Munshis are to be found on the north bank of the Benue River; but the greater number are on the south bank, their villages extending some distance in a southerly direction. They are an agricultural people of a primitive type, their live stock consisting of cattle of a small breed-sheep, goats, pigs, and fowls-none of which are plentiful. Living in small villages, they wear little clothing, but prefer to smear their bodies with camwood and oil.

The great ambition of the Munshi is to have many wives, and, in order to secure them, he has three ways open to him : he may purchase, he may exchange, or he may steal; in other words, elope with a young woman. As he desires wives it is up to him to secure them; it is quite the usual thing to see several young braves out looking for wives, each seeking to outshine the other in the general get-up of his person. The head is shaved, leaving fantastic designs of tufts of hair. Camwood is used in quantity; a black pigment made of the seeds of a gardenia is used in painting freehand designs on face and body. Fingers and toes are ornamented with brass and other rings, beads and other articles can be used in the lobes of the ears, beads around the nock, brass and other rings on the legs and arms, a blue and white cloth around the waist, a knife worn on the wrist, spears in hand, any curious article that will add to the general effect; and the young man, who in his youth had his front 
teeth filed, and his face and body cicatrised, is a most attractive individuality to the Munshi young woman.

Many wives are desirable, as the more wives, the more gardens, and consequently the more food. Among the men are skilled workers in metal and some clever weavers. They are all great hunters, using bows and poisoned arrows in their hunting. The women help in farming and in building; they make the pottery, cook the food, and are the hewers of wood and drawers of water.

During the time of the greatness of Wukari, the centre of the Jukun Empire, the Munshis were probably well south of the Benue; but as that empire declined and the Fulani expansion occurred the Jukuns were driven across the Benue. Zaria began to exercise suzerain rights over the Aragos, who had previously been tributary to Wukari, on the north bank of the river. Then came trouble with Keff, and the Haraba clan of the Munshis crossed the Benue and occupied the country from which the Jukuns had been driven. Whether these Munshis were invited or not it is difficult to say. The Munshis are a virile people, and are pushing their villages farther into the old Jukun kingdom each year.

Although known by the surrounding tribes and officially as Munshis, they themselves use the word Tivi as the name of their tribe, and Dzua Tiv (Munshi mouth) as the name of their language. Although divided up into clans, their language shows very little dialectical difference in the various clans. As a people they consider themselves superior to the surrounding tribes: consequently a Munshi woman may not marry out of the tribe. It would lower her. A man, on the other hand, may take wives from other tribes, and by so doing he raises the woman. Probably the quest for wives, and bringing in from other clans, has tended to keep the language somewhat free of dialect.

The language would appear to have been formed originally by the union and amalgamation of languages of quite distinct groups. For while it resembles Bantu in many ways, there are forms which are quite unlike Bantu. Probably a conquering race has brought its grammatical system, but has adopted some of the vocabulary of the conquered people. 
Some of the ways in which Munshi resembles Bantu are as follows :-

(a) Grammatically the language is built up on the principle of the concord, nouns being divided into several classes irrespective of gender. These classes, classified in this article from $A$ to $E$, are distinguished by various prefixes or suffixes.

(b) Pronouns are influenced by the class of noun to which they stand in relationship in a sentence.

For instance, the noun in the possessive takes a pronoun varying according to the class of noun used.

In Class "A " My bow would be Ada wam.

In Class "B" My heart " Ishuma yam.

The pronoun "wam" being made up of u-am of me; "yam" is made up of $\mathrm{j}-\mathrm{am}$ of me, the genitive sign changing with class of noun.

(c) A pronominal copula is used which varies according to class of noun. For example :-

Class "A." Where is the bow? would be Ada ngu hana?

" Where are the bows? " Mbada mba hana? Class "B." Where is the heart?" "Ishuma ngi hana?

" Where are the hearts?" "Asuma nga hana?

(d) The Munshi method of counting is very similar to Bantu, and in the numerals one to five is, with the exception of two (har), strikingly like primitive Bantu :

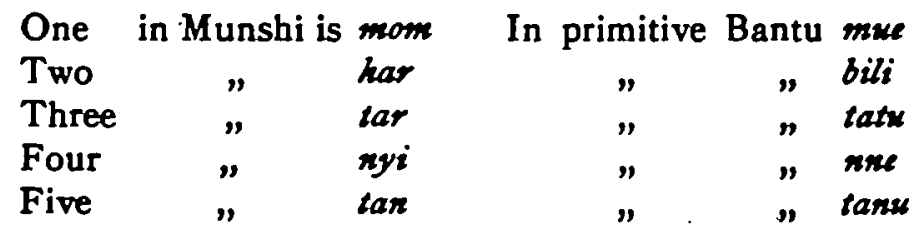

N.B. "Har" is used for two among the hill pagans of the Nassarawa Province, the Nungus, and others.

On the other hand, use is made in Munshi of one of the distinguishing features of true Negro speech, viz., the combinations "kp" and "gb." 
Again, in some cases the $3^{\text {rd }}$ person plural (ve, they) is used as a suffix in forming plurals, in spite of the fact that a prefix is also used. The use of the $3^{\text {rd }}$ person plural as a suffix, in forming plurals, is common to some of the Negro tribes.

Again, in the vocabulary there is a similarity to the languages spoken by neighbouring tribes.

The passive voice is not formed as in true Bantu, but as in Negro speech by the use of the pronoun 3 rd person plural. Thus : "I tinde' $m$," They sent me; lit., for I am sent. "Mba yilan mo"; lit., They are calling me, for I am being called.

\section{ThE Noun.}

Probably originally all Munshi nouns had a prefix, and according to the prefix the nouns grouped themselves naturally into classes. Modifications have taken place and it is not unusual to find nouns without a prefix.

Prefixes may have more than one form.

In the plural, nouns take a different form from that used in the singular.

A noun may belong to one class in the singular and to another in the plural.

\section{Class “ A."}

(1) Singular prefix "or" Plura] prefix " $m b a$ "

(2)" " $a$ " " " $m b a "$.

(3) No singular prefix " " "u, sometimes "uv"

Note.-There are exceptions, such as "0ro," a person. The plural of this is "ioro."

The form "or" is quite conceivably derived from "oro," a person. This form with its plural marks personal designation, e.g., "or-tesen," a teacher; plural, "mba-tesen," teachers.

Class " $A$ " corresponds to the chief class in most Bantu languages and is the largest class in Munshi.

(4) Diminutives of other classes are raised to this class by use of a diminutive plural. 
Examples of nouns in this class:-

Singular.

(I) Or-pirishe

Or-ihundu

(2) Ada

Anyam

(3) Gambe

Dagi

(4) Waniyongo

Wanigo
Pinerel.

mba-pirasho

mba-ihurdu

Mbada

mbanyam

ugambe

udagi

onov mbayongo

onov mbaigo blind person

mad person

a bow (the weapon)

leopard

bed

spear

lamb

porker

\section{Class " $B . "$}

(1) Singular prefix * $i$

(2) "

$"$
Plural prefix " $a$ " $~$
" "

When the plural is " $i$," stress is laid on the prefix and the vowel is pronounced longer than in the singular prefix.

Examples :-
(I) Ioan
avan
Iho
aho
(2) Igo
igo
arow
knife
pig
goat

When the root of the noun commences with palatals "ch," " $\mathrm{j}$," or "sh," these change to the dental sibilants "ts," " $\mathrm{dz}$," or " $s$ " in the plural. This is apparently for euphony.

Examples:-

$\begin{array}{lll}\text { Ichul } & \text { atsul } & \text { forehead } \\ \text { Ijume } & \text { adsume } & \text { back } \\ \text { Ishuma } & \text { asuma } & \text { heart }\end{array}$

There are a number of nouns in Class " $A$ " which in the plural are treated as Class "B." In all such cases the pronominal change agrees with Class "B."

$$
\text { Class "C." }
$$

Nouns in this class seem to have lost their prefix, although often in both singular and plural they commence with "i." 
There is, however, a general ending in the singular, a slight guttural sound written in these notes "gh."

There is a plural ending of " $v$," often very indistinctly enunciated.

Examples :-

$\begin{array}{lll}\text { Ijogh } & \text { ijov } & \text { iron } \\ \text { Ishigh } & \text { ishiv } & \text { face }\end{array}$

\section{Class " $D . "$}

This class consists chiefly of nouns that might be regarded as collective. This class has only one number. The prefix is the nasal " $\mathrm{m}$. "

Many nouns in this class end in " $m$ "; this may have been caused by running the pronominal copula on to the noun, thus: "mgeri ma hana?" Where is the water? has become "Mgerim ma hana?" It is travelling on the water, is "Ngu drende sha mger," the last syllable being dropped.

Examples :-

$\begin{array}{ll}\text { Mgerim } & \text { water } \\ \text { Myim } & \text { smoke }\end{array}$

\section{Class "E."}

This is a very small class, consisting largely of abstract words. No prefix is used, but the suffix " $v$ " is the usual ending. Nouns in this class are treated as if plural.

Examples:-

$$
\begin{array}{ll}
\text { Chiev } & \text { fear } \\
\text { Tsav } & \text { witchcraft }
\end{array}
$$

$$
\text { Class " } F \text {." }
$$

This is also a small class of nouns. There is a suffix which is generally used in the singular, viz., "gh." The plural prefix is "a."

Examples :-

$\begin{array}{lll}\text { Uwegh } & \text { ave } & \text { hand } \\ \text { Gbagh } & \text { agba } & \text { camwood }\end{array}$


The possessive case of nouns is expressed by a possessive particle, the sign of the genitive, changing according to class of noun.

Examples :-

Class “A." Adambusu u Ganyi
" “" Mbadambusu mba Ganyi
Class "B." Iwange i nomsor
" " " Awange a nomsor
Class "C." Inyaregh ki Tsonka

The Jukun's cat The Jukun's cats the man's spear the man's spears the Hausa's goods (collectively)

., Inyareo mbi Tsonka the Hausa's goods The Munshi's beer Class "D." Msorom ma Tiv the chief's sickness Class "E." Angev mbu tor Class "F." Uwe ku waniye the boy's hand the boy's hands

The division of nouns into classes is not based on distinction of sex. Gender in its meaning of sex has no influence whatever on the "structure of the language. Pronouns may be translated he, she, or it according to the noun represented.

When it is desired to mark gender in a noun the prefix "nom," a male, or "mbyan," a female, is used, as the case may require.

$\begin{array}{lll}\text { Nomkegh a cock } & \text { mbyankegh a hen } \\ \text { Nomninya } & \text { a stallion } & \text { mbyanninya a mare }\end{array}$

Another way to express sex would be to say "Ngu nyinya $u$ nom," It is a stallion. "Ngu ninya u kwase," It is a mare (kwase is the usual word for female or a woman).

The diminutive noun is formed by prefixing "wan," a child, to the noun, thus : iwa, a dog, becomes waniwa, a pup; iya, a village, becomes waniya, a small village. The plural diminutive is formed by the prefix "onov." Pups would be "onov mbaiwa," lit., children of a dog. "An" is also used in the same way in the plural. Thus, "aniwav mba $u$ hap" is two pups.

N.B. " $v$ " is added to the noun.

Wan would appear to be formed thus: " $u$ ana." The genitive " $u$ " of Class " $A$ " prefixed to ana (the final " $a$ " is 
sometimes heard). No genitive is used in the plural to follow "an."

\section{Personal Pronouns.}

The personal pronouns occur in six different forms of cases :-

(1) used as subject

(2) " object

(3) " copula

(4) " substantive

(5) after a preposition

(6) in the possessive

$M$ gbidyeun
A gbidye m
ngu her
ka mo
sha a na
iho yam

I beat him he beat me

it is here

it is $I$

to him

my knife

(1) Pronouns used as subject:-

$\begin{array}{llll} & & \text { Singuler. } & \text { Plural. } \\ & \text { Ist. } & m & \text { se } \\ \text { 2nd. } & u & \text { ne } \\ \text { Class "A." } & \text { 3rd. } & a & v e, i, m b a \\ \text { Class "B." } & i & i, a \\ \text { Class "C." } & k i & m b i \\ \text { Class "D." } & \text { (none) } & m a \\ \text { Class "E." } & \text { (none) } & m b u \\ \text { Class "F." } & k u & a\end{array}$

(2) Pronouns used as object :-
Singuler. Plusal.
Ist person $m$ se
2nd person $n$, we ne
Class "A." $u n, n a$ ve

Classes " $B$ " to " $F$ " as in the pronoun used as subject; although it is not unusual to hear the 3 rd person of Class " $A$ " used in the other classes, when the pronoun is used as object.

(3) Pronouns used as copula :-

The pronominal copula in Munshi does duty for a word or particle such as "is" or "are" in English. It connects a subject with its predicate. It may do duty for the subject. It thus becomes possible by the use of the copula to make a sentence without the use of a verb, as "ngu," for instance, is equivalent to "it is." 
The pronominal copulas are used as follows :-

Class "A." Kwase ngu hana? Where is the woman?

" Kaseo mba hana? Where are the women?

Class "B." Ishe ngi hana? Where is the eye?

" Ashe nga hana? Where are the eyes?

Class "C." Iyogh ki hana? Where is the iron?

" Iyov mbi hana? Where are the irons?

Class "D." Msorom mba hana? Where is the beer?

Class "E." Tsav mbu hana? Where is the fetich?

Class "F." Uwegh ku hana? Where is the hand?

" Ave nga hana? Where are the hands?

There is another particle, "ka," which also does duty as a copula. It is used in emphatic and direct speech, as " $k a$ do, It is good.

(4) Pronouns used as substantive :-

When the pronoun stands alone it takes its fullest form. In meaning the pronoun used as substantive is always more or less emphatic.

The use of these pronouns is as follows :-

$\begin{array}{llll}K a \text { mo } & \text { It is I } & K a \text { se } & \text { It is we } \\ k a \text {. } & \text { it is thou } & k a n e & \text { it is you } \\ K a \text { ma } & \text { it is he } & k a v e & \text { it is they }\end{array}$

(5) Pronouns used after a preposition :-

The pronoun, when used after a preposition, as indirect object, takes practically the same form as it does when used after a transitive verb. In the singular of Class " $A$ " the forms generally used are :-

$\begin{array}{llll}\text { Ist person } & \ldots & \ldots & \text { mo } \\ \text { and person } & \ldots & \ldots & \text { we } \\ \text { 3rd person } & \ldots & \ldots & \text { na }\end{array}$

The following sentences illustrate this use :- ${ }^{\alpha} V_{B}$ mba oron kwa a mo," They are speaking to me; "Se mba oron kwa a we," We are speaking to thee; " $M$ nenga sha na ga," I do not look after him.

In the case of the verb "hungul," to forget, which contains the prepositional idea, the same forms in the Ist and and 
person are used. There are other verbs similar, which contain the prepositional idea.

Example :-

$\begin{array}{ll}\text { Hungul mo } & \text { I forget (lit., Forgotten by me) } \\ \text { Hungul we } & \text { thou forgettest } \\ \text { Hungul un } & \text { he forgets }\end{array}$

(6) Pronouns in the possessive :-

Possessive pronouns vary according to the noun with which they agree. They were probably made up originally of a particle denoting the genitive and the representative pronoun. This is seen in "wam," my-made up of " $u$," of, and "am," me; also in "wase," our, made up of " $u$," of, and "ase," us.

To say, The walking-stick is mine, the copula " $k a{ }^{\prime \prime}$ is used, thus: "Aga ka u wam," The walking-stick is mine; "Mbaga ka mba av," The walking-stick is ours.

A. S. JUDd.

(To be continued.) 